\title{
Variability in Wood Density and Wood Fibre Characterization of Woody Species and Their Possible Utility in Northeastern Mexico
}

\author{
Humberto Gonzalez Rodriguez ${ }^{1 *}$, Ratikanta Maiti ${ }^{1}$, Aruna Kumari² ${ }^{2}$ N. C. Sarkar ${ }^{3}$ \\ ${ }^{1}$ Facultad de Ciencias Forestales, Universidad Autónoma de Nuevo León, Linares, México \\ ${ }^{2}$ Crop Physiology, Professor Jaya Shankar Telangana State Agricultural University, Agricultural College, \\ Jagtial, India \\ ${ }^{3}$ Department of ASEPAN, Institute of Agriculture, Birbhum, India \\ Email: "humberto.gonzlez@uanl.mx,ratikanta.maiti@gmail.com,arunasujanagcjgl@gmail.com, \\ ncsiari@gmail.com
}

Received 5 April 2016; accepted 22 May 2016; published 25 May 2016

Copyright (C 2016 by authors and Scientific Research Publishing Inc.

This work is licensed under the Creative Commons Attribution International License (CC BY).

http://creativecommons.org/licenses/by/4.0/

(c) $\underset{\mathrm{EY}}{\mathrm{Br}}$ Open Access

\begin{abstract}
Context: Preliminary screening has been undertaken by woody species of Tamaulipan thornscrub for wood density and its utilization northeastern Mexico for different purposes and to find possible relationship of density with wood fibre characteristics. This technique can be used in the selection of species with high wood density for possible utility. Aims: It is to determine the variability in wood density and in fiber cell morphology and its length and among wood species of the Tamaulipan thornscrub, northeastern Mexico. Methods: Wood density and wood fibres are characterized in these woody species following standard methodology. Results: The results reveal large variability in wood density and in fibre cell morphology $h$. The species have been classified on the basis of wood density and its fibber cell morphology and has been recommended for their possible utilization for different purposes. Conclusions: Species desirable for strong furniture making, paper pulp, soft furniture, fence etc. can be selected on the basis of fibre length to breadth ratios as strong fibres for furniture and fibre cells with broad lumen and thin cell wall use for fabrication of paper pulp and other utilities.
\end{abstract}

\section{Keywords}

Woody Plants, Wood Density, Fibre Characterization, Variability, Wood Fibres, Tamaulipan

*Corresponding author.

How to cite this paper: Rodriguez, H.G., Maiti, R., Kumari, A. and Sarkar, N.C. (2016) Variability in Wood Density and Wood Fibre Characterization of Woody Species and Their Possible Utility in Northeastern Mexico. American Journal of Plant Sciences, 7, 1139-1150. http://dx.doi.org/10.4236/ajps.2016.77109 


\section{Thornscrub}

\section{Introduction}

The shrubs and trees of the Tamaulipan thornscrub in the semiarid regions of the northeastern Mexico are of great economic importance for various uses such as timber for furniture, fence, post, firewood and sources of forage for wild grazing animals for possessing macro- and micro-nutrients required by animals, herbs, medicine and reforestation [1].

Wood density contributes to the quality of a timber and its utility in wood industry. Wood density is an important variable in carbon cycle research. It offers resistance in the trees against wind, storms, cavitation of xylem vessels, and other environmental stresses. Reyes et al. [2] determined wood density of tropical tree species. Wood density for a large number of tropical tree species is determined in units of ovendry weight in grams per cubic centimeter of green volume. The data base includes 1280 entries from tropical America (40 percent), tropical Asia (36 percent), and tropical Africa (24 percent). The most frequent wood densities vary from 0.5 to $0.8 \mathrm{~g} / \mathrm{cm}^{3}$.

Bhat et al. [3] studied wood density and fibre length of Eucalyptus grandis grown in Kerala, India in trees of four age groups (3, 5, 7 and $9 \mathrm{yr}$ ). The average basic density was $495 \mathrm{~kg} / \mathrm{m}^{3}$ at $3 \mathrm{yr}$ and there was no significant increase from 3 to $9 \mathrm{yr}$, whereas 5-yr-old trees had a significantly lower value. Fibre length increased consistently with age; fibres of 3 -yr-old trees (mean $0.81 \mathrm{~mm}$ ) were about $29 \%$ shorter than those of 9 -yr-old trees $(1.15 \mathrm{~mm})$. Density did not show significant differences but differed significantly between the locations, but fibres were longer in one location where trees had faster growth. Density decreased from stump to $25 \%$ of tree height and then gradually increased towards the top in a curvilinear manner, whereas fibre length commonly showed the reverse trend. In 5, 7- and 9-yr-old trees, average tree density could be predicted with reasonable accuracy using breast height density, but stump level density was a better predictor of average tree density in 3yr-old trees.

For accurate estimates of the carbon stocks present in the world's tropical forests, there is a growing need for accurate tree biomass estimations on large spatial scales Chave et al. [4], Cummings et al. [5], Nascimento and Laurance [6]. Wood-specific gravity is an important component of these biomass estimations Baker et al. [7], Magcale-Macandog [8], Nogueira et al. [9].

Wood density predicts life-history strategies of tree species, as it is closely related to tree growth rates [10]. On the other hand, wood density is positively related to drought resistance in tropical trees Hacke et al. [11], Meinzer [12], Slik [13]. This indicates that high wood density is positively correlated with xylem wallen forcement, which reduces cavitation risk due to strong tensions during periods of drought [11]. Baker et al. [7] observed that the wood density of tree species in Neotropical forests was a taxonomically conserved trait, whereby variation in wood density was mainly explained by the wood density at generic level.

Several studies on wood density have shown that community-level wood density varies considerably among neotropical forests Wiemann and Williamson [14], Baker et al. [7], Muller-Landau [15] and therefore is considered a predictive variable in large-scale tropical biomass estimation protocols Baker et al. [7], DeWalt and Chave [4], Jerome Chave et al. [16]. Baker et al. [7] observed that wood density across 59 Amazonian plots and four Neotropical forests, respectively, was negatively associated with soil fertility. In this respect at a broader scale, Wiemann and Williamson [14] made a comparative study of North American and South American communities, and observed a positive correlation between wood density and mean annual precipitation. On the contrary, Steege and Hammond [17] observed that the variation in mean wood density within Guyana did not show correlation with either precipitation or soil fertility, whereas in Mexico, Barajas Morales [18] found that mean wood density was negatively related to precipitation. All these studies report contrasting trends in the regional and environmental variability of wood density, although they were based on a limited number of study sites or were restricted to one region of the neotropics. Density is correlated with cavitation resistance. This is safety factor against implosion of xylem to avoid collapse (Owe Hacke et al. [11] [19]).

Santiago et al. [20] investigated the relation between transport capacity and wood density. Wood density and wood anatomy with leaf photosynthetic traits in two low land Panamanian forest. Leaf specific hydraulic conductivity of the upper branches was positively correlated with the maximum rates of net $\mathrm{CO}_{2}$ assimilation per 
unit leaf area and stomatal conductivity. Maximum leaf hydraulic conductivity showed stronger correlation with net $\mathrm{CO}_{2}$ assimilation. This suggests that allocation to photosynthetic potential is proportional to maximum water transport. Branch wood density was negatively correlated with wood water storage and wood water potential.

Jérôme Chave et al. [16] studied regional and phylogenetic variation of wood density across 2456 neotropical trees species. According to them, wood density is a crucial variable in carbon accounting programs of both secondary and old-growth tropical forests. It also is the best single descriptor of wood: it correlates with numerous morphological, mechanical, physiological, and ecological properties. In order to explore the estimation of wood density, and possible sources of variation in this trait, they analyzed regional, taxonomic, and phylogenetic variation in wood density among 2456 tree species from Central and South America. Wood density varied over more than one order of magnitude across species, with an overall mean of $0.645 \mathrm{~g} / \mathrm{cm}^{3}$. Their geographical analysis showed significant decreases in wood density with increasing altitude and significant differences among low-altitude geographical regions: while wet forests of Central America and Western Amazonia have significantly lower mean wood density than dry forests of Central and South America, Eastern and Central Amazonian forests, and the Atlantic forests of Brazil; and Eastern Amazonian forests have lower wood densities than the dry forests and the Atlantic forest. A nested analysis of variance revealed that $74 \%$ of the species-level wood density variation was explained at the genus level, 34\% at the Angiosperm Phylogeny Group (APG) family level, and 19\% at the APG order level. This reveals that genus-level means give reliable approximations of values of species, except in a few hypervariable genera. They also studied that evolutionary shifts in wood density occurred in the phylogeny of seed plants using a composite phylogenetic tree. Major changes were observed at deep nodes (Eurosid 1), and also in more recent divergences (for instance in the Rhamnoids, Simaroubaceae, and Anacardiaceae). Their unprecedented wood density data set yields consistent guidelines for estimating wood densities when species-level information is lacking and should significantly reduce error in Central and South American carbon accounting programs.

According to Hugo Martínez-Cabrera [21] wood density plays a key role in ecological strategies and life history variation in woody plants, but very little is known about its anatomical basis in shrubs. They quantified the relationships between wood density, anatomy, and climate in 61 shrub species from eight field sites along latitudinal belts between 31 and 35 in North and South America. Measurements included cell dimensions, transverse areas of each xylem cell type and percentage contact between different cell types and vessels.

Conifers are the most important source of raw material for the Mexican timber industry, besides they are a source of environmental services and are habitat of many living organisms. Pablo Martínez-Antúnez et al. [22] undertook density estimation of conifer species from environmental variables. Twenty species of conifers of five different genus and eleven environmental variables were analyzed. The results indicated that there is a small linear relationship between the abundance of the species and the analyzed predictors. However, some of the results indicate that the abundance for $60 \%$ of the selected conifer species is affected by at least four environmental variables, including mainly, the precipitation during the growing season (April to September), the average length of the frost-free period, the altitude above the sea level and the mean annual precipitation.

\section{Materials and Methods}

A study was undertaken to determine the variability in fiber cell morphology and its length among thirty sevenwood species of the Tamaulipan thornscrub, northeastern Mexico at the experimental station of Facultad de Ciencias Forestales, Universidad Autonoma de Nuevo Leon, located in the municipality of Linares (2447N. $9932 \mathrm{~W}$ ), at elevation of $350 \mathrm{~m}$. The climate is subtropical or semiarid with warm summer, monthly mean air temperature vary from $14.7^{\circ} \mathrm{C}$ in January to $23^{\circ} \mathrm{C}$ in August, although during summer the temperature goes up to $45^{\circ} \mathrm{C}$. Average annual precipitation is around $805 \mathrm{~mm}$ with bimodal distribution.

\section{The Study Consists of Two Stages}

\subsubsection{Determination of Wood Density of 37 Woody Species}

Wood density in these woody species is determined by collecting 10 pieces of wood of each of $5 \mathrm{~cm}$ long from the branches of the tree of each species.

These wood pieces were then dried in an oven at $80^{\circ} \mathrm{C}$ for 3 days cooled and weighed in a desiccator to avoid absorption of moisture from the atmosphere. The wood piece was later dipped in water in a measuring cylinder for measuring the volume of the wood. The density of wood was calculated as follows: 


$$
\text { Density }=\frac{\text { Weight of wood }(\mathrm{g})}{\text { Volume }\left(\mathrm{cm}^{3}\right)}
$$

\subsubsection{Characterization of Wood Fibres of Few Selected Species Varying in Wood Density}

We selected few woods varying in wood density for wood fibre characterization. Sample woods for fibre characterization. We did fibre characterization of the selected species varying in wood density. One disk of $0.1 \mathrm{~m}$ thick was taken from two primary branch of a tree from each species. Few small pieces of wood of each species were dipped in concentrated nitric acid and plugged with cotton. Then the test tubes are kept in boiling water bath until the wood pieces started disintegrating. Then acid was decanted slowly and the macerated wood elements were washed several times with distilled water. Then, the macerated fiber cells were stained with safranin (1\%) and observed under microscope and taken photographs with digital camera fixed with microscope.

\section{Results}

\subsection{Wood Density}

The results showed that the thirty seven woody species of Tamaulipan thornscrub Northeastern Mexico differed in wood density and fibre characteristics. The wood density exhibited by these 37 species is shown in Table 1 .

It is observed that the woody species (trees and shrubs) belonging to different families showed a large variation in Wood density ranging from 0.511 to $1.09 \mathrm{~g} / \mathrm{cm}^{3}$.

In the following Table 2 is show Kwalis analysis.

The species showed significant different differences $(<0.001)$. In the following Figure 1 is shown large variability in density among 37 woody species in Northeast Mexico.

Thespecies of high density were Acacia schaffneri $\left(1.10 \mathrm{~g} / \mathrm{cm}^{3}\right)$, Fraxinus greggii $\left(1.02 \mathrm{~g} / \mathrm{cm}^{3}\right)$, Helietta parvifolia $\left(1.00 \mathrm{~g} / \mathrm{cm}^{3}\right)$, the species with médium density were Croton suaveolens $\left(0.91 \mathrm{~g} / \mathrm{cm}^{3}\right)$, Karwinskia humboldtiana $\left(0.88 \mathrm{~g} / \mathrm{cm}^{3}\right)$, Acacia farnesiana $\left(0.81 \mathrm{~g} / \mathrm{cm}^{3}\right)$, and the species with low density Diospyros texana $\left(0.64 \mathrm{~g} / \mathrm{cm}^{3}\right)$, Forestiera angustifolia, Cordia boissieri $\left(0.63 \mathrm{~g} / \mathrm{cm}^{3}\right)$ Salix lasiolepis $\left(0.51 \mathrm{~g} / \mathrm{cm}^{3}\right)$.

On the basis of the results of wood density we can classify woody species in the following:

Very hard: Acacia shaffneri (1.096), Fraxinus gregii (1.016), Helietta parviflora (0.998). Bernardia myricifolia (0.975).

Hard: Acacia rigidula (0.974), Quercus virginiana (0.962), Berberis chococo (0.961), Prosopis laevigata (0.953). The Woods of these species could be recommended for manufacture of furniture and doors.

Medium hard: Gymnosperma glutinosum (0.942), Sargentia gregii (0.929), Croton suaveolens (0912), Eysenhardtia polystachya (0.910), Ebenopsis ébano (0.909), Cercidium macrum (0.901). These species could be recommended for soft wood furniture, fences, fire wood, vegetablecarbón.

Soft: Acacia wrighttii (0.896), Karwinskia humboldtiana (0.884) Acacia berlandieri (0.875), Amyris texana (0.863). These species may be used for fire wood or paper pulp depending on fibre cell characteristics.

Very soft: Leucaena leucocephala (0.6733), Zanthoxylum fagara (0.6610), Diospyros texana (0.642), Forestiera angustifolia (0.6338), Cordia boissieri (0.6258), Salix lasiolepis (0.513). These Woods may be used for fire Wood, fences etc.

\subsection{Characterization of Wood Fibres of the Selected Woody Species Varying in Wood Density}

In the following Table 3 is shown the fibre cell dimensions of 30 species only.

One can select species desirable for strong furniture making, paper pulp, soft furniture, fence etc.

It is observed that there exists large variation in wood fibre cell dimension on the basis of which we can classify species.

Species with very long fibre cells (>500 $\mu \mathrm{m})$ : Quercus polymorpha (709.39), Celtis laevigata (657.58), Helietta parvifolia (647.78), Ehretia anacua (644.66), Acacia farnesiana (598.58) Ziziphus obtusifolia (591.09), Acacia rigidula (581.53), Gochnatia hypoleuca (563.30), Fraxinus greggii (535.67), Cordia boissieri (518), Karwinskia humboldtiana (507.33), Acacia shaffneri (501.17). It is to be considered that for imparting strength, 
Table 1. The Wood density of 37 woody species of Tamaulipan thornscrub.

\begin{tabular}{|c|c|c|c|c|c|c|}
\hline Name common & Name scientific & Family & type & Leaf type & $\begin{array}{l}\text { Density } \\
\mathrm{g} / \mathrm{cm}^{3}\end{array}$ & SD \\
\hline Huizache chino & Acacia shaffneri & Fabaceae & Tree & compuesta & 1.0960 & 0.0591 \\
\hline Barreta china & Fraxinus greggii & Oleaceae & Tree & compuesta & 1.0165 & 0.1298 \\
\hline Barreta & Helietta parvifolia & Rutaceae & Shrub & compuesta & 0.9986 & 0.1702 \\
\hline Oreja de ratón & Bernardia myricifolia & Euphrobiaceae & Shrub & simple & 0.9752 & 0.0919 \\
\hline Chaparroprieto & Acacia rigidula & Fabaceae & Shrub & compuesta & 0.9749 & 0.0926 \\
\hline Encino & Quercus virginiana & Fabaceae & Tree & simple & 0.9622 & 0.1889 \\
\hline paloamarillo & Berberis chococo & Berberidaceae & Shrub & compuesta & 0.9611 & 0.1077 \\
\hline Mezquite & Prosopis laevigata & Fabaceae & Tree & compuesta & 0.9536 & 0.0771 \\
\hline Tatalencho & Gymnosperma glutinosum & Asteraceae & Shrub & simple & 0.9422 & 0.1349 \\
\hline Chapoteamarillo & Sargentia gregii & Rutaceae & Tree & compuesta & 0.9296 & 0.1264 \\
\hline Salvia & Croton suaveolens & Euphrobiaceae & Shrub & simple & 0.9121 & 0.1371 \\
\hline Varadulce & Eysenhardti apolystachya & Fabaceae & Shrub & compuesta & 0.9105 & 0.0837 \\
\hline Ebano & Ebenopsis ebano & Fabaceae & Tree & compuesta & 0.9096 & 0.0652 \\
\hline Palo verde & Cercidium macrum & Fabaceae & Tree & compuesta & 0.9010 & 0.1042 \\
\hline Uña de gato & Acacia wrightt & Mimosaceae & Tree & compuesta & 0.8968 & 0.0821 \\
\hline Coyotillo & Karwinskia humboldtiana & Rhamnaceae & Shrub & Simple & 0.8846 & 0.0802 \\
\hline Huajillo & Acacia berlandieri & Fabaceae & Tree & compuesta & 0.8756 & 0.0631 \\
\hline Barretilla & Amyris texana & Rutaceae & Shrub & compuesta & 0.8631 & 0.0725 \\
\hline Brasil & Condalia hoockeri & Rhamnaceae & Tree & Simple & 0.8507 & 0.1432 \\
\hline Anacua & Ehretia anacua & Boraginaceae & Tree & simple & 0.8236 & 0.1188 \\
\hline Lantana & Lantana macropoda & Verbenaceae & Shrub & simple & 0.8210 & 0.2520 \\
\hline Huizache & Acacia farnesiana & Fabaceae & Shrub & compuesta & 0.8080 & 0.0902 \\
\hline Cenizo & Leucophyllum frutescens & Scrophulariaceae & Shrub & simple & 0.7868 & 0.1827 \\
\hline Coma & Bumelia celastrina & Sapotacee & Tree & simple & 0.7853 & 0.0775 \\
\hline Guayacan & Guaiacum angustifolium & Zygophyllaceae & Shrub & compuesta & 0.7836 & 0.1423 \\
\hline Granjeno & Celtis pallida & Ulmaceae & Shrub & simple & 0.7768 & 0.0649 \\
\hline Retama & Parkinsonia aculeata & Fabaceae & Tree & compuesta & 0.7568 & 0.0868 \\
\hline Chapotemanzano & Diospyros palmeri & Ebenaceae & Tree & simple & 0.7222 & 0.0637 \\
\hline Palo blanco & Celtis laevigata & Ulmaceae & Tree & simple & 0.7170 & 0.0349 \\
\hline Tenaza & Harvadia pallens & Fabaceae & Tree & compuesta & 0.7065 & 0.0608 \\
\hline Hierba del potro & Caesalpinia mexicana & Fabaceae & Tree & compuesta & 0.6927 & 0.0372 \\
\hline Leucaena & Leucaena leucocephala & Fabaceae & Tree & compuesta & 0.6733 & 0.0809 \\
\hline Colima & Zanthoxylum fagara & Rutaceae & Shrub & compuesta & 0.6610 & 0.0430 \\
\hline Chapoteprieto & Diospyros texana & Ebenaceae & Tree & simple & 0.6420 & 0.0548 \\
\hline Panalero & Forestiera angustifolia & Oleaceae & Shrub & simple & 0.6338 & 0.0325 \\
\hline Anacahuita & Cordia boissieri & Boraginaceae & Tree & Simple & 0.6258 & 0.0467 \\
\hline Sauce & Salix lasiolepis & Salicaceae & Tree & simple & 0.5138 & 0.0423 \\
\hline
\end{tabular}


Table 2. Kwalis analysis of 37 woody species of Tamaulipan thornscrub.

\begin{tabular}{ccc}
\hline & Statistical & \\
\hline Variable & $\chi^{2}$ & Valor $\mathrm{p}$ \\
Density $\left(\mathrm{g} / \mathrm{cm}^{3}\right)$ & 254.92 & $<0.001$ \\
\hline
\end{tabular}

Table 3. Fibre cell dimensions of 30 species.

\begin{tabular}{|c|c|c|c|c|c|c|c|c|}
\hline \multirow{2}{*}{ Specie } & \multicolumn{2}{|c|}{$\begin{array}{l}\text { FIBRE CELL } \\
\text { LENGTH } \mu \mathrm{m}\end{array}$} & \multicolumn{2}{|c|}{ BREADTH $\mu \mathrm{m}$} & \multicolumn{2}{|c|}{$\begin{array}{l}\text { CELL WALL } \\
\text { THICKNESS } \mu \mathrm{m}\end{array}$} & \multicolumn{2}{|c|}{$\begin{array}{c}\text { LENGTH/ } \\
\text { BREADTHBER }\end{array}$} \\
\hline & Average & Std & Average & Std & Average & Std & Average & Std \\
\hline Acacia berlandieri & 464 & 159.70 & 23.52 & 7.40 & 2.98 & 1.42 & 19.73 & 21.58 \\
\hline Acacia farnesiana & 598.58 & 255.24 & 16.66 & 8.22 & 2.94 & 1.10 & 35.93 & 31.05 \\
\hline Acacia shaffneri & 501.17 & 248.84 & 16.85 & 9.90 & 2.94 & 1.48 & 29.74 & 25.14 \\
\hline Acacia wrightii & 438.06 & 214.92 & 15.68 & 6.56 & 2.89 & 0.95 & 27.94 & 32.76 \\
\hline Bernardia myricifolia & 450.59 & 105.04 & 22.73 & 8.72 & 3.13 & 1.48 & 19.82 & 12.05 \\
\hline Caesalpinia mexicana & 464.71 & 110.31 & 20.18 & 8.49 & 3.28 & 1.75 & 23.03 & 12.99 \\
\hline Capsicum anпиит & 437.26 & 93.12 & 18.62 & 10.33 & 2.84 & 1.03 & 23.48 & 9.01 \\
\hline Celtis laevigata & 657.58 & 246.60 & 17.64 & 12.04 & 3.08 & 1.46 & 37.28 & 20.48 \\
\hline Celtis pallida & 471.97 & 162.82 & 14.11 & 6.9 & 3.08 & 1.08 & 33.45 & 23.60 \\
\hline Condalia hookeri & 398.47 & 161.13 & 17.64 & 10.09 & 3.23 & 1.52 & 22.59 & 15.97 \\
\hline Cordia boissieri & 518.03 & 155.09 & 16.46 & 7.25 & 3.72 & 1.8 & 31.47 & 21.39 \\
\hline Croton terreyanus & 453.53 & 101.78 & 14.73 & 7.67 & 3.23 & 1.15 & 30.79 & 13.27 \\
\hline Diospyros palmeri & 486.47 & 152.47 & 18.03 & 8.48 & 3.08 & 1.08 & 26.98 & 17.98 \\
\hline Ehretia anacua & 644.66 & 270.67 & 11.56 & 3.8 & 4.45 & 3.11 & 55.77 & 71.23 \\
\hline Eysenhardtia polystachya & 477.65 & 96.88 & 19.99 & 8.62 & 2.84 & 1.14 & 23.89 & 11.24 \\
\hline Forestiera angustifolia & 488.43 & 72.21 & 23.91 & 5.99 & 4.80 & 0.85 & 20.43 & 12.06 \\
\hline Fraxinus greggii & 535.67 & 150.90 & 17.64 & 13.42 & 2.74 & 1.17 & 30.37 & 11.24 \\
\hline Gochnatia hypoleuca & 563.30 & 176.16 & 17.24 & 5.79 & 2.94 & 1.21 & 32.67 & 30.42 \\
\hline Helietta parvifolia & 647.78 & 209.75 & 15.48 & 4.88 & 2.94 & 1.3 & 41.85 & 42.98 \\
\hline Karwinskia humboldtiana & 507.33 & 219.48 & 15.68 & 10.47 & 3.08 & 1.19 & 32.36 & 20.96 \\
\hline Lantana macropoda & 391.60 & 86.18 & 14.30 & 7.97 & 2.59 & 0.76 & 27.38 & 10.81 \\
\hline Leucophyllum frutescens & 438.45 & 94.49 & 16.66 & 7.47 & 3.08 & 1.19 & 26.32 & 12.65 \\
\hline Morus celtidifolia & 454.72 & 130.86 & 15.68 & 6.26 & 2.74 & 0.80 & 29 & 20.90 \\
\hline Parkinsonia aculeata & 473.33 & 110.03 & 31.64 & 8.55 & 6.86 & 0.98 & 14.96 & 12.87 \\
\hline Prosopisla evigata & 412.97 & 190.85 & 10.78 & 2.96 & 2.84 & 0.90 & 38.31 & 64.48 \\
\hline Quercus polymorpha & 709.39 & 190.17 & 13.72 & 6.26 & 2.59 & 0.58 & 51.70 & 30.38 \\
\hline Salix lasiolepis & 455.11 & 150.25 & 16.07 & 6.78 & 3.43 & 1.30 & 28.32 & 22.16 \\
\hline Zantoxyllum fagara & 454.13 & 155.8 & 16.07 & 8.57 & 3.23 & 1.15 & 28.26 & 18.18 \\
\hline Ziziphus obtusifolia & 591.09 & 150.72 & 20.58 & 7.20 & 2.98 & 1.33 & 28.72 & 20.93 \\
\hline
\end{tabular}

several factors need to be mentioned such as not only length, but also wall thickness, length breadth ratio are important. It is expected that the species having long fibres are expected to produce strong wood or strong paper pulp. Some of the species viz. Acacia farnesiana, Cordia biosiieri Leucophyllum leucocephala have desirable 


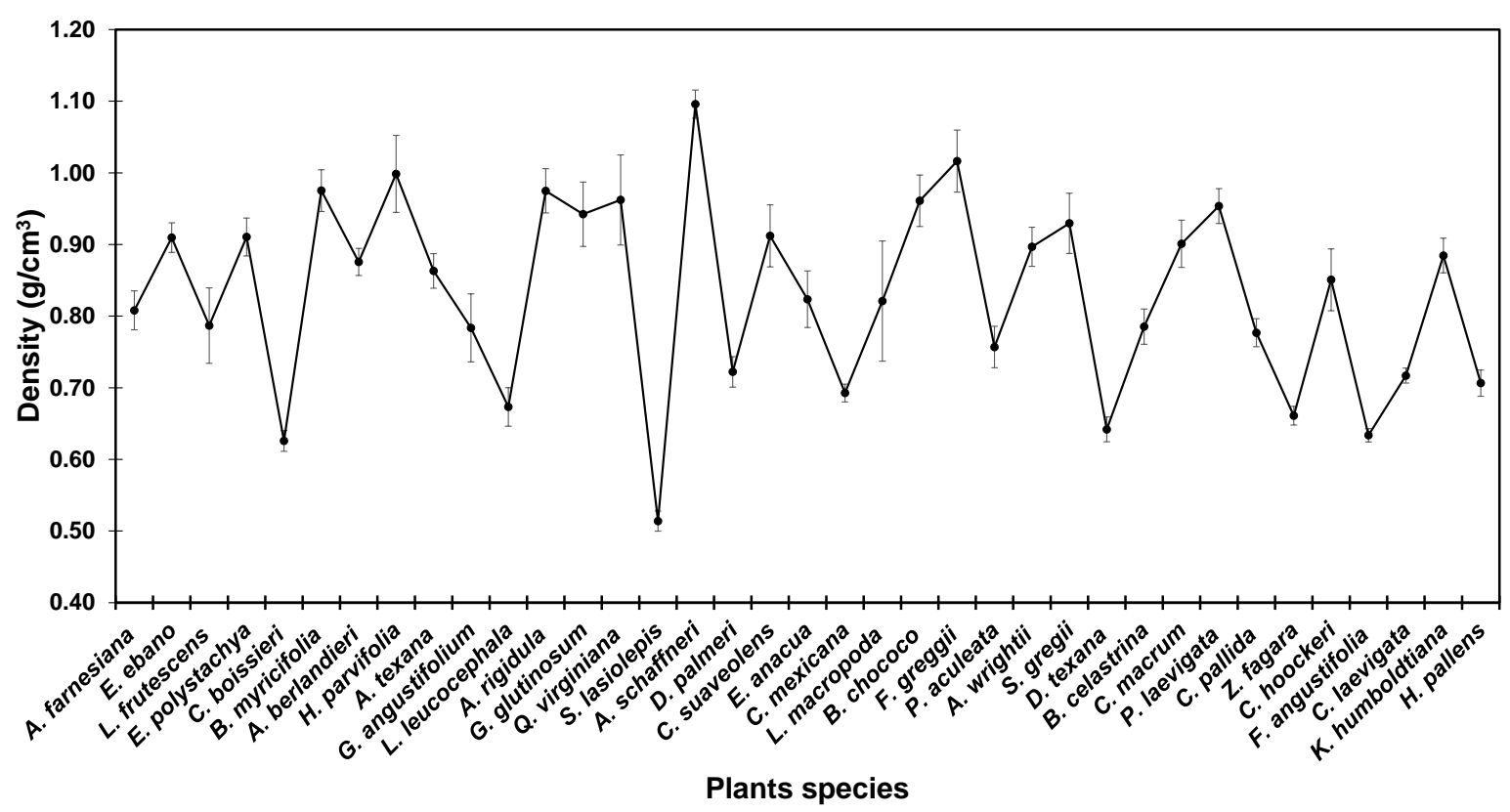

Figure 1. Variability in wood density of thirty seven species of Tamaulipan thornscrub.

characteristics for good paper pulp for having one bigger fibre breadth and thin cell wall.

The species having high value of length/breadth ratio of fibre cells are expected to produce strong wood fibres were: Ehretia anacua (55.77), Quercus polymorpha (51.71), Helietta parvifolia (41.85), Prosopis laevigata (38.31), Celtis laevigata (37.28), Acacia farnesiana (33.95), Celtis pallida (33.45), Gochnatia hypoleuca (32.67), Karwinskia humboldtiana (32.36), Cordia boissieri (31.47). These could be recommended for paper pulp manufacture also.

Species having broad breadth are expected to be desirable for paper pulp production which could be selected from the table.

In the following are depicted the wood fibre cell morphology of the selected woody species. A large variability is seen in the fibre length, breadth and lumen of the wood fibres of these species.

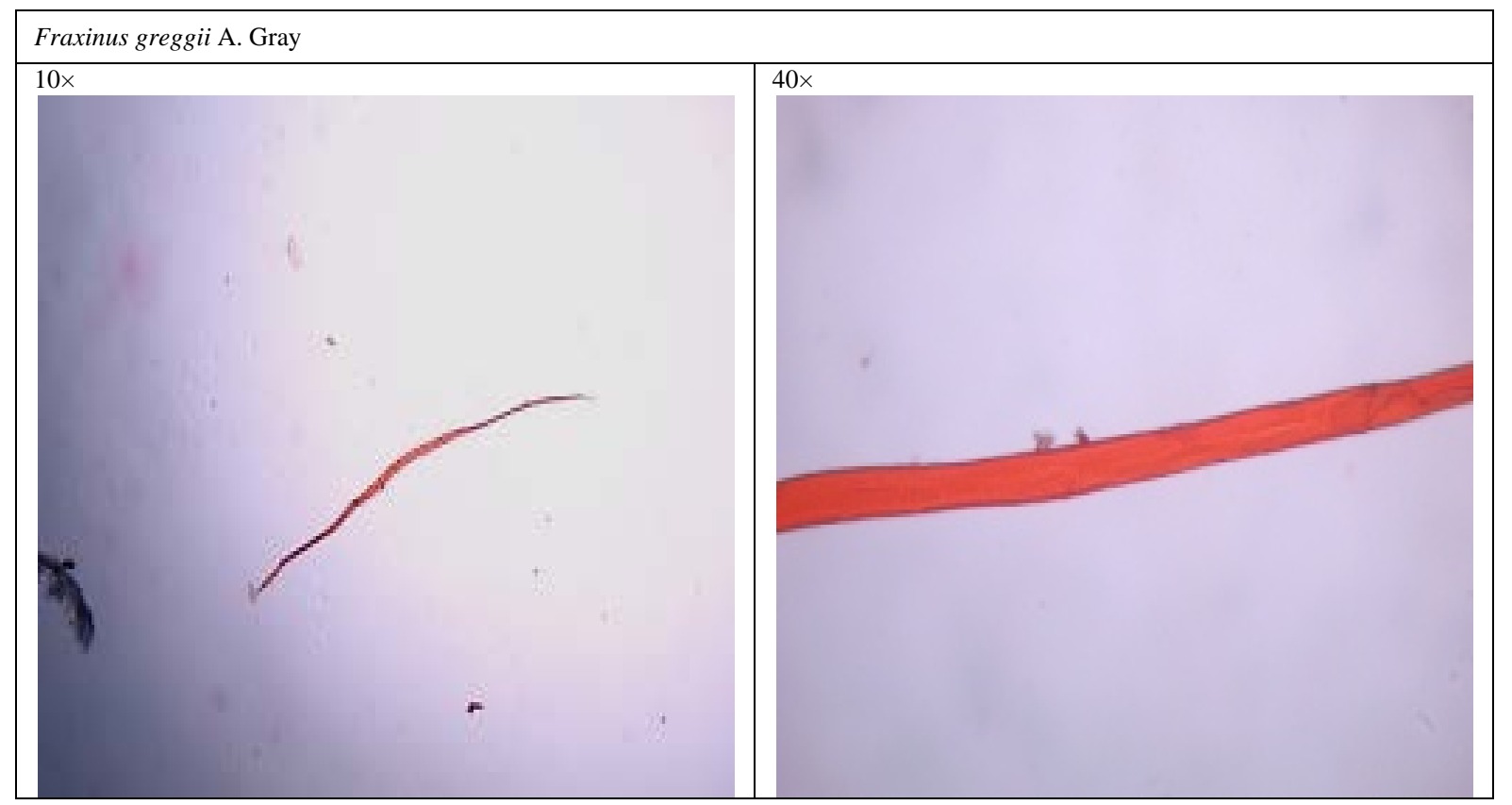



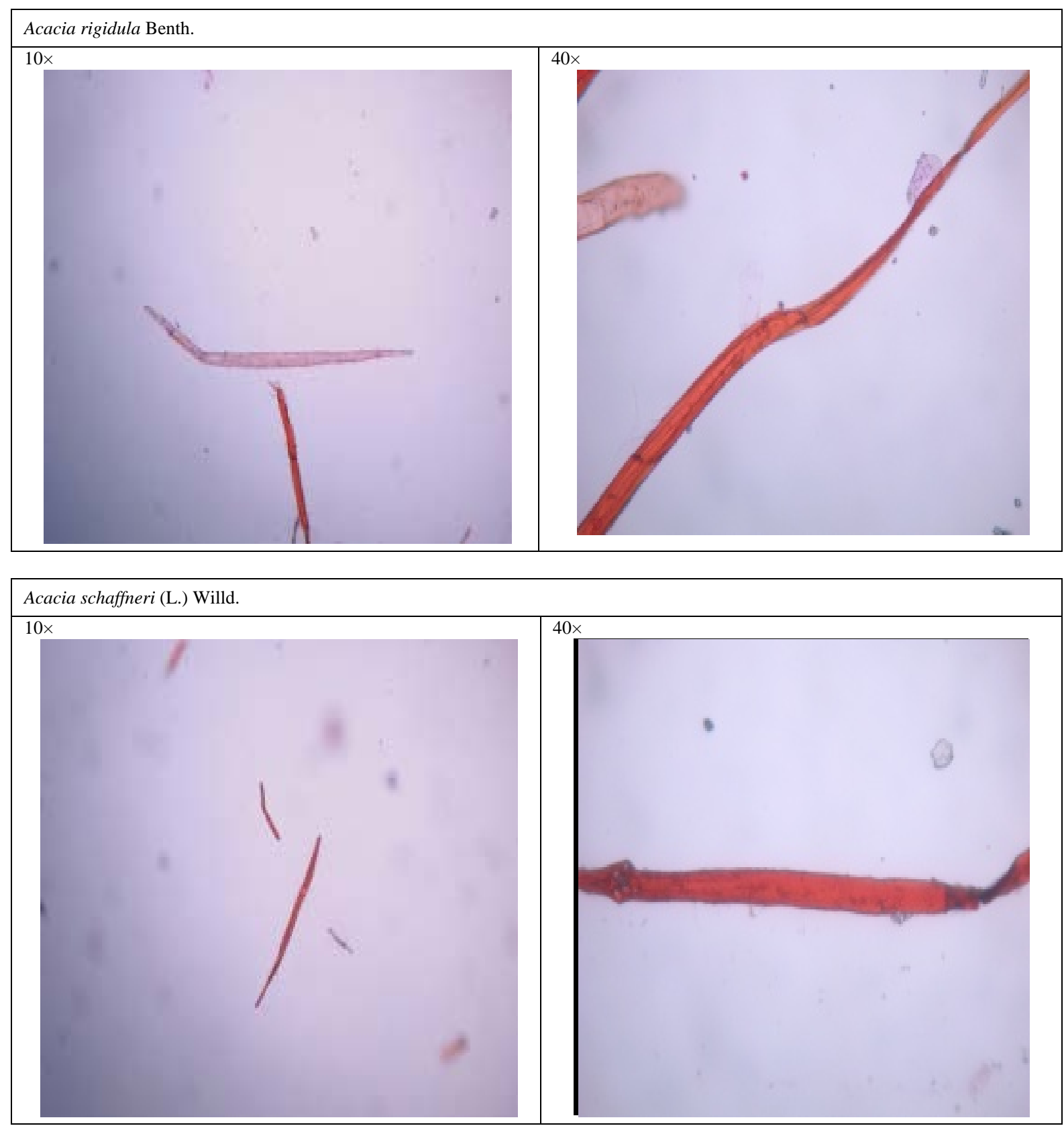

Bernardia myricifolia (Scheele) Benth. \& Hook. f.

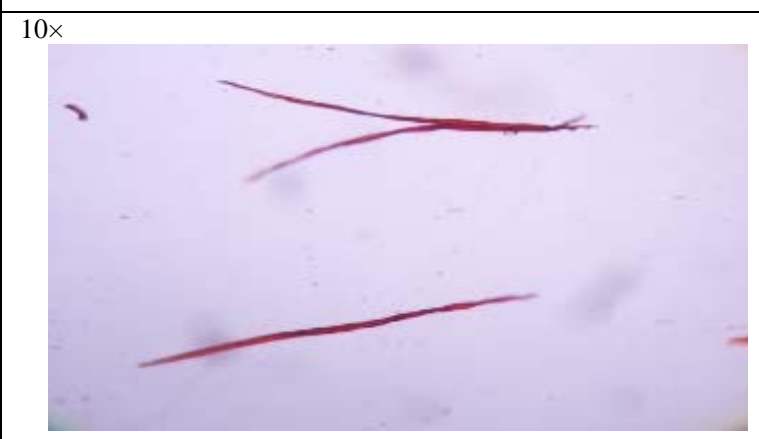

$40 \times$

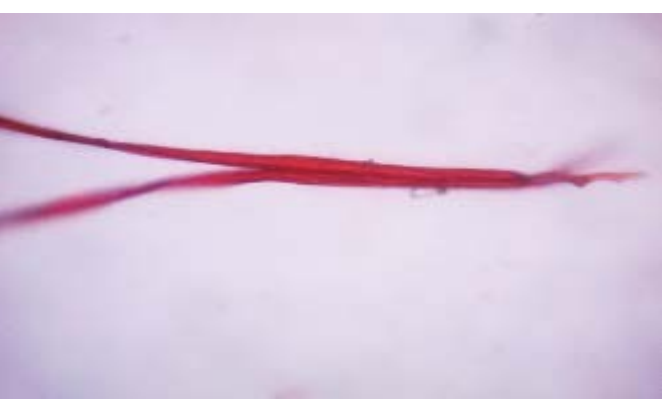




\section{Medium Hard}
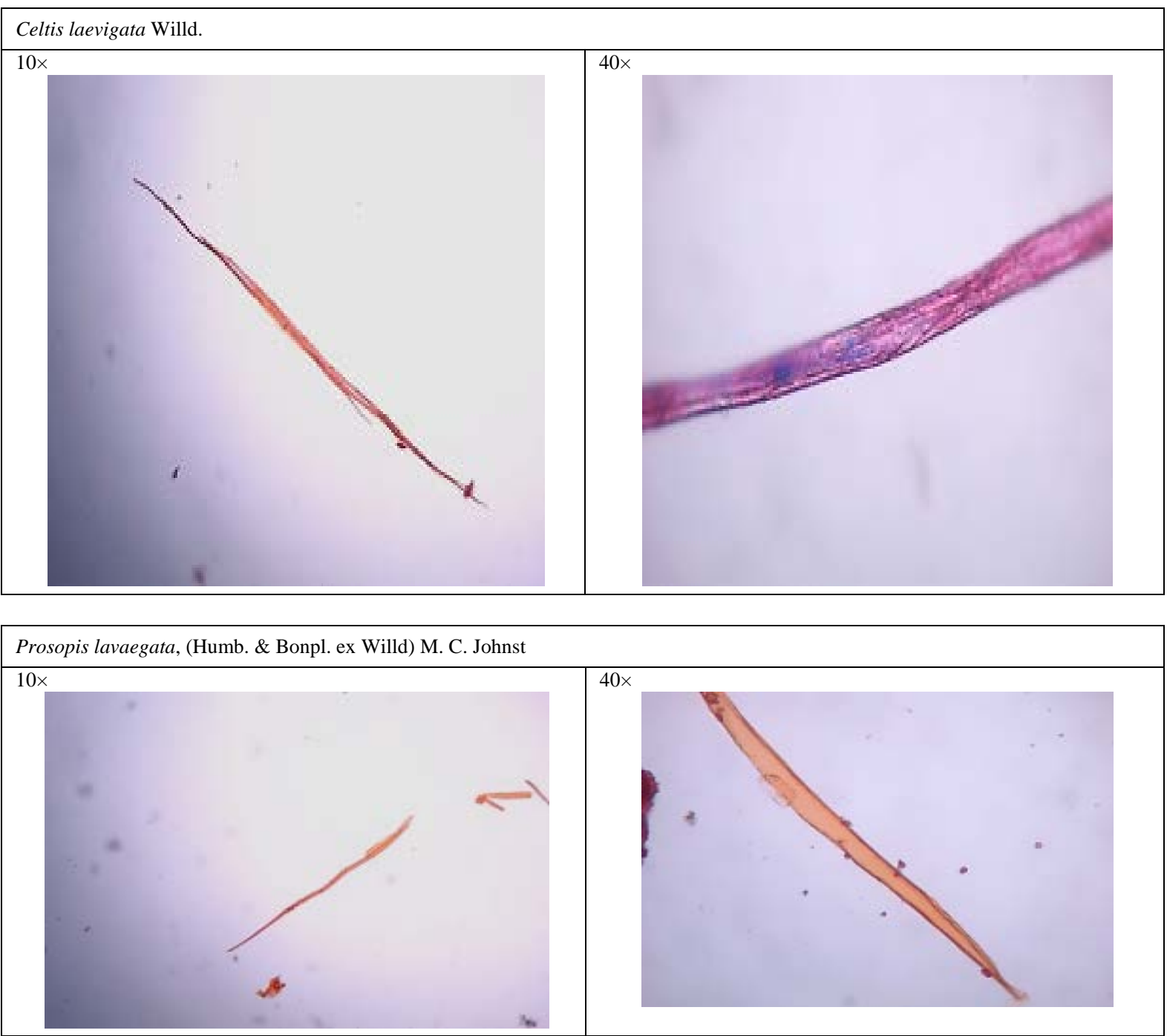

\section{Very Soft}

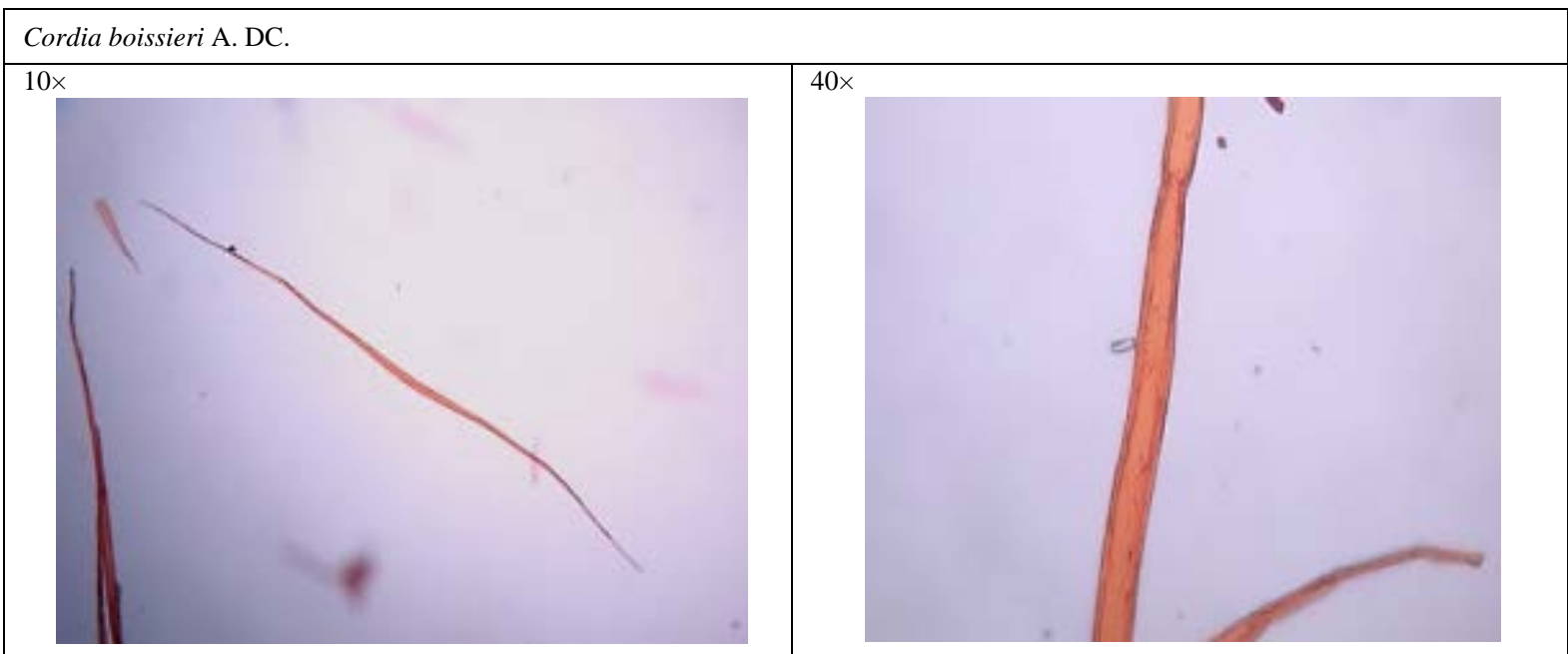




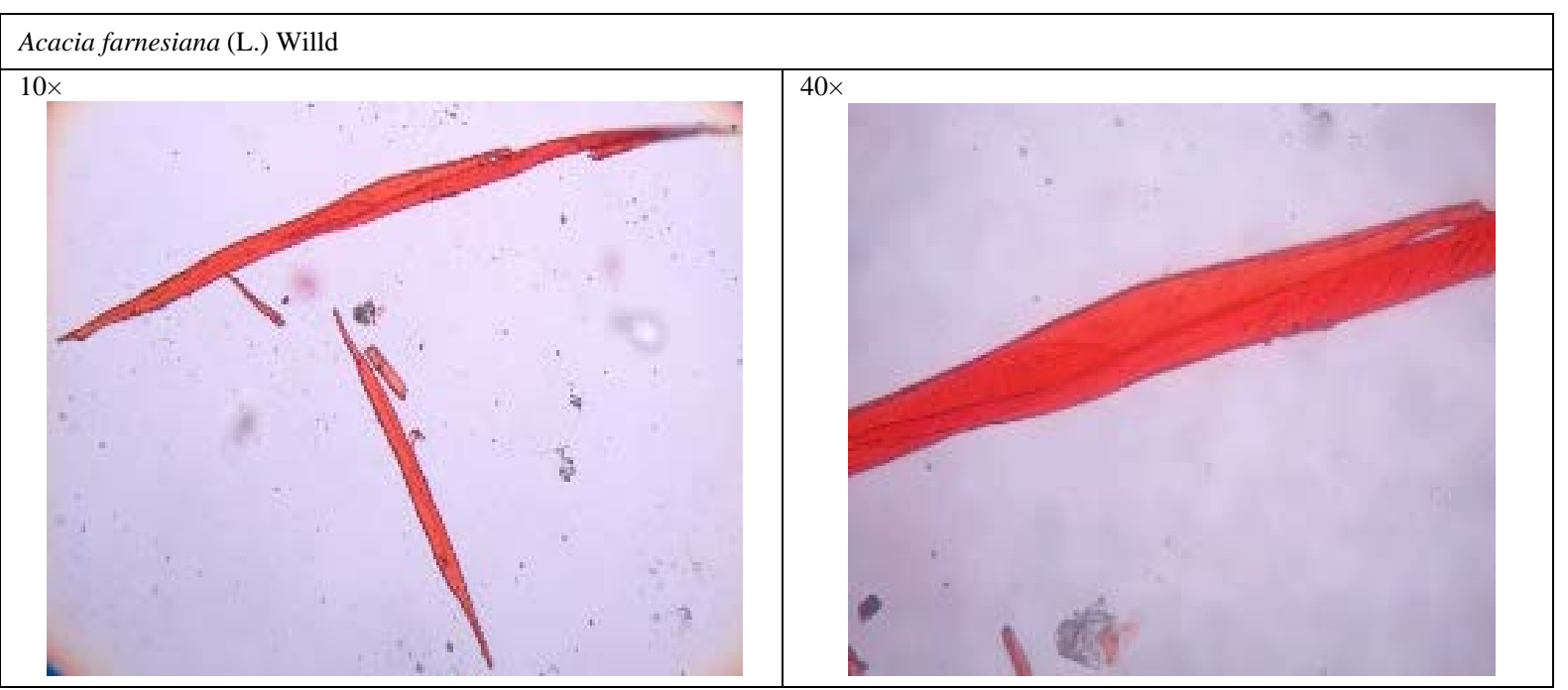

It is observed that in general the species having high wood density (hard) possess thick fibre cell wall and narrow lumen, while those with low density (soft wood) possess thin cell wall and broader lumen.

\section{Discussion}

In the present study, there exists a large variability in wood density among 37 woody species in Northeastern Mexico. It is observed that the following species with very hard to hard woods possess open canopy where all leaves are exposed to solar radiation for efficient photosynthesis and probably high carbón fixation. Acacia shaffnei $\left(1.01 \mathrm{~g} / \mathrm{cm}^{3}\right)$, Bernardia myricifolia $\left(0.97 \mathrm{~g} / \mathrm{cm}^{3}\right)$, Acacia rigidula $\left(0.97 \mathrm{~g} / \mathrm{cm}^{3}\right)$. The species with semiclose leaf canopy possess médium hard wood Ebenopsis ébano $\left(0.96 \mathrm{~g} / \mathrm{cm}^{3}\right)$, Acacia wrightii $\left(0.89 \mathrm{~g} / \mathrm{cm}^{3}\right)$. The following species with close leaf canopy possess very soft wood Diospyros texana $\left(0.64 \mathrm{~g} / \mathrm{cm}^{3}\right)$, Forestiera angustifolia $\left(0.83 \mathrm{~g} / \mathrm{cm}^{3}\right)$, Cordia boissieri $\left(0.62 \mathrm{~g} / \mathrm{cm}^{3}\right)$. The variability in wood density enables in selection of species with hard, medium or soft wood for use in the manufacture of furniture, doors and others.

It is well known that wood density contributes to the quality of wood and its utility in wood industry. In this respect, the results of the present study coincide with the findings of several authors in determining wood density of woody species in different geographical regions. Variability in wood density is reported in tropical tree species [2] [5] [16]. The present study on wood density is located only in one location showing large variability among species thereby giving opportunity to select desirable species for timber production. It is well documented that wood density varies in different ecological condition. Wood density is positively related to drought resistance [11] [12]. On the other hand, wood density is negatively associated with soil fertility [7]. Similarly Wieman and Wiliamsen [14] working on North American species show positive association with precipitation. Wood density plays a vital role in the ecological strategies of woody plants [20].

Wood fibre cell length and cell wall thick contribute a lot to wood quality for which wood technologists are interested to determine wood fibre dimensions. One can select species desirable for strong furniture making, paper pulp, soft furniture, fence etc. Variability in wood fibre dimensions and its possible relation with wood quality and utility is reported by Maiti et al. [23] in woody species of Northeastern Mexico. It is observed that in general species having high wood density possess fibre thick cell wall and thin lumen which needs to be confirmed in future study. In the present study, we studied morphology of woods of only selected woody species varying in wood density. Variability in wood density and fibre length was observed at different ages of Eucalyptus grandis Bhat Blar Dharmadharaan [24]. It is well documented in vegetable fibres that the species having long fibre cell length and high length/breadth ratio contribute to strong fibres used for cordage, gunny bags and other textile materials. While the species having high breadth/lumen breadth and thin wall are suitable for fabrication of paper pulp [25] [26] and also by the present study we observe that the species with high wood density have high cell wall thickness while those with less low density (soft wood) have low cell wall thickness. With respect to fibre cell characterization, one can select species desirable for strong furniture making, paper pulp. Soft furniture, fence etc. It is well documented in vegetable fibres that the species having long fibre cell length 
and high length/breadth ratio contributed to strong fibres used for cordaje, gunny bags and other textile materials paper pulp [25] [26].

It is well documented in vegetable fibres that the species having long fibre cell length and high length/breadth ratio contributed to strong fibres used for cordaje, gunny bags and other textile materials. While the species having high breadth/lumen breadth and thin wall are suitable for fabrication of paper pulp [25] [26].

Species having high wall thickness are expected to produce strong fibre for high lignification which could be selected from the table. The results on fibre dimensions in the present study coincide with the findings by several authors mentioned before for its possible utility with respect to variability in fibre cell dimensions .Though the present study was concentrated on the characterization of fibre cells Maiti et al. [23], various studies have documented on the properties of wood fibre cells and their utility in wood and paper industry.

\section{Acknowledgements}

The authors are highly thankful to Elsa Gonzalez for dedicated hard work in the wood density analysis to our full satisfaction.

\section{References}

[1] Reid, N., Marroquín, J. and Beyer, M.P. (1990) Utilization of Shrubs and Trees for Browse, Fuel-Wood and Timber in the Tamaulipan Thornscrub, Northeastern Mexico. Forest Ecology and Management, 36, 61-79. http://dx.doi.org/10.1016/0378-1127(90)90064-I

[2] Reyes, G.S., Chapman, B.J. and Lugo, A.E. (1992) Wood Densities of Tropical Tree Species. General Technical Report SO-88. USDA Forest Service, Southern Forest Experiment Station, New Orleans, Louisiana.

[3] Blar, B.K. and Dharmadharaan, K.V.T. (1990) Wood Diameter and Fibre Length of Eucalyptus grandis Growth in Kerala, India. Wood and Fiber Science, 22, 54-59.

[4] De Walt, S.J. and Chave, J (2004) Structure and Biomass of Four Lowland Neotropical Forests. Biotropica, 36, 7-19. http://dx.doi.org/10.1111/j.1744-7429.2004.tb00291.x

[5] Cummings, D.L., Kauffman, J.B., Perry, D.A. and Hughes, R.F. (2002) Aboveground Biomass and Structure of Rainforests in the Southwestern Brazilian Amazon. Forest Ecology and Management, 163, 293-307. http://dx.doi.org/10.1016/S0378-1127(01)00587-4

[6] Nascimento, H.E.M. and Laurance, W.F. (2004) Biomass Dynamics in Amazonian Forest Fragments. Ecological Applications, 14, S127-S138. http://dx.doi.org/10.1890/01-6003

[7] Baker, T.R., et al. (2004) Variation in Wood Density Determines Spatial Patterns in Amazonian Forest Biomass. Global Change Biology, 10, 545-562. http://dx.doi.org/10.1111/j.1365-2486.2004.00751.x

[8] Magcale-Macandog, D.B. (2004) Comparative Evaluation of Different Approaches to Estimate Aboveground Biomass and Biomass Density of Tropical Forests in Southeast Asia: A Review. The Philippine Agricultural Scientist, 87, 6175.

[9] Nogueira, M., Nelson, B.W. and Fearnside, P.M. (2005) Wood Density in Dense Forest in Central Amazonia, Brazil. Forest Ecology and Management, 208, 261-286. http://dx.doi.org/10.1016/j.foreco.2004.12.007

[10] Verburg, R., Tersteege, H. and Zagt, R. (2003) Long-Term Changes in Tropical Tree Diversity: Synthesis and Implications for Management. 175-215.

[11] Hacke, U.G., Sperry, J.S., Pockman, W.T., Davis, S.D. and MCculloh, K.A. (2001) Trends in Wood Density and Structure Are Linked to Prevention of Xylem Implosion by Negative Pressure. Oecologia, 126, 457-461. http://dx.doi.org/10.1007/s004420100628

[12] Meinzer, F.C. (2003) Functional Convergence in Plant Responses to the Environment. Oecologia, 134, 1-11. http://dx.doi.org/10.1007/s00442-002-1088-0

[13] Slik, J.W.F. (2004) El Nino Droughts and Their Effects on Tree Species Composition and Diversity in Tropical Rainforests. Oecologia, 141, 114-120. http://dx.doi.org/10.1007/s00442-004-1635-y

[14] Wiemann, M.C. and Williamson, G.B. (1988) Extreme Radial Changes in Wood Specific Gravity in Some Tropical Pioneers. Wood Fiber Science, 20, 344-349.

[15] Muller-Landau, H.C. (2004) Interspecific and Intersite Variation in Wood Specific Gravity of Tropical Trees. Biotropica, 36, 20-32.

[16] Chave, J., Muller-Landau, H.C., Baker, T.R., Easdale, T.A., ter Steege, H. and Webb, C.O. (2006) Regional and Phylogenetic Variation of Wood Density across 2456 Neotropical Tree Species. Ecological Applications, 16, 2356-2367. 
http://dx.doi.org/10.1890/1051-0761(2006)016[2356:RAPVOW]2.0.CO;2

[17] Ter Steege, H. and Hammond, D.S. (2001) Character Convergence, Diversity, and Disturbance in Tropical Rain Forest in Guyana. Ecology, 82, 3197-3212. http://dx.doi.org/10.1890/0012-9658(2001)082[3197:CCDADI]2.0.CO;2

[18] Barajas-Morales, J. (1987) Wood Specific Gravity in Species from Two Tropical Forests in Mexico. International Association of Wood Anatomists Journal, 8, 143-148. http://dx.doi.org/10.1163/22941932-90001041

[19] Hacke, U.G., Sperry, J.S., Pockman, W.T., Davis, S.D. and McCulloh, K.A. (2001) Trends in Wood Density and Structure Are Linked Prevention of Xylem Implosion by Negative Pressure. Oecologia, 126, 457-461. http://dx.doi.org/10.1007/s004420100628

[20] Santiago, L.S., Goldstein, G., Meinzer, F.C., Fisher, J.B., Machado, K., Woodruff, D. and Jones, T. (2004) Leaf Photosynthesis Traits Scale with Hydraulic Conductivity and Wood Density in Panamanian Forest Canopy Trees. Oecologia, 140, 543-550. http://dx.doi.org/10.1007/s00442-004-1624-1

[21] Martínez-Cabrera, H.I., Jones, C.S., Espino, S. and Schenk, H.J. (2009) Wood Anatomy and Wood Density in Shrubs Responses to Varying Aridity along Transcontinental Transects. American Journal of Botany, 96, 1388-1398. http://dx.doi.org/10.3732/ajb.0800237

[22] Martínez-Antúnez, P., Hernández-Díaz, J.C., Wehenkel, C. and López-Sánchez, C.A. (2015) Estimación de la densidad de especies de coníferas a partir de variables ambientales. Density Estimation of Conifer Species from Environmental Variables. Madera y Bosques, 21, 23-33.

[23] Maiti, R., Para, A.C., Rodriguez, H.G. and Paloma, S.V. (2015) Characterization of Wood Fibres of Scrubs and Tree Species of the Tamaulipan Thornscrub, Northeastern Mexico and Its Possible Utilization. Forest Research, 4, 154.

[24] Bhat, K.M., Bhat, K.V. and Dhamodaran, T.K. (1990) Remove from Marked Records Wood Density and Fibre Length of Eucalyptus grandis Grown in Kerala, India. Wood and Fiber Science, 22, 54-61.

[25] Maiti, R.K. (1997) World Fibre Crops. Science Publishers, Lebanon and Oxford \& IBH Co Pvt. Ltd., New Delhi, 352.

[26] Maiti, R., Gonzalez-Rodriguez, H. and Satya, P. (2011) Horizon of World Plant Fibres: An Insite. Pushpa Publishing House, New Delhi, 178. 